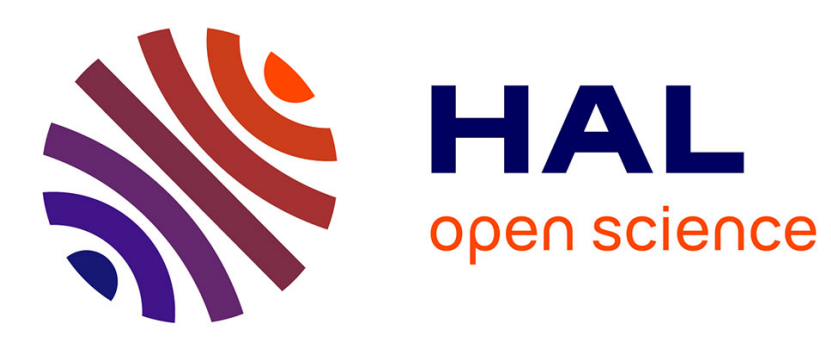

\title{
Academic Career, Mobility and the National Gender Regimes in Switzerland and Finland
}

Terhi Nokkala, Pierre Bataille, Taru Siekkinen, Gaële Goastellec

\section{To cite this version:}

Terhi Nokkala, Pierre Bataille, Taru Siekkinen, Gaële Goastellec. Academic Career, Mobility and the National Gender Regimes in Switzerland and Finland. Leasa Weimer; Terhi Nokkala. Universities as Political Institutions, Brill, pp.262-286, 2020, 10.1163/9789004422582_012 . hal-02539311v2

\section{HAL Id: hal-02539311 \\ https://hal.science/hal-02539311v2}

Submitted on 10 Apr 2020

HAL is a multi-disciplinary open access archive for the deposit and dissemination of scientific research documents, whether they are published or not. The documents may come from teaching and research institutions in France or abroad, or from public or private research centers.
L'archive ouverte pluridisciplinaire HAL, est destinée au dépôt et à la diffusion de documents scientifiques de niveau recherche, publiés ou non, émanant des établissements d'enseignement et de recherche français ou étrangers, des laboratoires publics ou privés. 


\title{
Academic Career, Mobility and the National Gender Regimes in Switzerland and Finland
}

\author{
Terhi Nokkala, Pierre Bataille, Taru Siekkinen and Gaële Goastellec
}

Référence originale

Nokkala T., Bataille P., Siekkinen T., Goastellec G. (2020), "Academic Career, Mobility and the National Gender Regimes in Switzerland and Finland". In Weimer L. and Nokkala T. Universities as Political Institutions, Brill :Leyde, 262-286. https://doi.org/10.1163/9789004422582012

\section{Résumé}

The probability of reaching a permanent academic position is strongly gendered in most if not all higher education systems. Though a widely studied phenomenon, few studies problematise the way national contexts - both academic and non-academic - that shape employment structures and national gender regimes are interpreted by individual academics, and frame their career strategies and the ways of subjectively coping with the norms of academic careers. Aiming to fill this research gap, this chapter compares the subjective representations of early career academics in terms of career expectation and articulation between professional and private sphere in two contrasted national contexts; Finland and Switzerland. Focusing especially on international mobility, the paper aims to reveal how national polities matter to understand young academics' strategies and how these strategies are shaped - or not - by gender relationships in the era of the so called 'internationalisation' of academic labour markets and the norm of the academic staff mobility ${ }^{a}$.

a We dedicate this chapter to the memory of our colleague and friend prof. Kelly Ward, whose work significantly contributed to a better understanding of gendered academic careers and whose management of the work-family and more generally work-life balance has been and shall long remain a source of inspiration. Kelly participated to the panel in which this paper was presented in the CHER 2017 Jyväskylä conference with her usual enthusiasm and sense of sharing. She will be deeply missed.

\section{Introduction}

As many scientific research and public reports underline, in most national higher education systems, the probability of reaching a permanent academic position is strongly gendered: women having largely less chances than men to access such positions, even if they represent a growing part of the academic staff at the doctoral and postdoctoral levels (Bozzon, Murgia, \& Poggio, 2018). This 'leaky pipeline' phenomenon is well identified in the literature combining gender and academic career analysis (Goulden, Meison, \& Frasch 2011; Dubois-Shaik, Fusulier, \& Vincke, 2018).

While there are many investigations into this topic that mobilise data from different national contexts (see for example Eggins, 2017; Goastellec \& Pekari, 2013), few studies really problematise how far national contexts (academic and nonacademic) that shape employment structures and national gender regimes also guide the academics' career strategies i.e., how gender inequalities in academia are embedded into national specific contexts (Goastellec \& von Roten, 2017). In this 
paper, we compare the subjective representations of early career academics in terms of career expectations and articulation between professional and private spheres in two contrasted national contexts (Finland and Switzerland). Our paper aims to unravel how national polities matter to understanding young academics' strategies and how these strategies are shaped - or not - by gender relationships in the era of the so called 'internationalisation' of academic labour markets, where international mobility has increasingly become a norm for academic careers. We investigate how the international norm of academic mobility influences the academic careers for men and women, depending on the national gender regime in which the academic market they try to access is embedded.

We use the concept of gender regime to highlight the gendered aspects of societal structures, policies, norms and customs that enable or constrain the differential participation of men, women and those of other gender identity in society and employment. According to Acker (1994, p. 117), the gender regime concept refers to "the patterning of gender processes in particular social units at particular historical times". Units can be national space, institutions or professional groups for instance. In the context of higher education, the notion of gender regime also highlights the structural and political aspects that are sometimes disguised by the seeming meritocracy of academia (Le Feuvre, 2009). We consciously use the term 'polity' to denote the "set of collective choices linking together parts submitted to the rule of "compulsory belongings"' (Leca, 2012, p. 62) that are embedded in the national context. Instead of the notion of policies, which refer to the contents and implementation of specific rules, such as gender equality policy, maternity policy or recruitment policy, we use the notion of polities to comprise multiple policies but also the tacit understandings and cultures within the national boundaries that frame the Swiss and Finnish gender regimes. We approach the gender regimes from the perspective of individual academic's perceptions regarding the frameworks that facilitate and constrain their choices.
By doing so, we acknowledge that gender regimes participate in the social regulation and thus impinge on the values, norms and roles individuals internalise through the socialisation process, leading individuals to develop dispositions which are 'situated' with regard to their context of 'interiorisation' (Lahire, 1998).

The rest of this paper is structured as follows: in Section 2, we frame our paper in terms of the varied elements of the leaky pipeline phenomenon; and present our research questions. To better understand the observed diversity of the leaky pipeline, we propose to look closer at how representations and practices of young researchers in terms of academic career and mobility are shaped by the national gender regime and the way academic careers are nationally regulated. In Section 3, we outline the context of internationalisation of academic labour markets and the national gender regimes in Finland and Switzerland, as well as introduce the data and method of the study. Section four describes the findings of the study along the four dominant dimensions systematically discussed by the interviewees: internationalisation, career, family and work-life balance. We conclude by discussing the similarities and differences in how the early career academics, in Finland and Switzerland, talk about career, international mobility, family and work-life balance.

\section{Varieties of 'leaky pipelines'}

\section{The gendering of academic careers as a politically 'embedded' phenomenon}

Although women represent equal or higher student numbers in undergraduate and graduate education or in the early stages of an academic career, they still face many obstacles in advancing on their career path (Rogers \& Molinier, 2016).

Cross-national comparisons show that, depending on the national academic system, the 'flow' of women exiting the higher level of the academic hierarchy 
strongly vary - as does the way they exit (Le Feuvre, 2009). Thus, if "it is undoubtedly true that women all over the world are victims of discrimination and of the effects of patriarchal stereotypes and that their academic careers are less 'successful' than those of their male counterparts [...] there are [however] considerable differences, both between countries and [...] between disciplinary fields, and there are also signs of considerable change over time" (Le Feuvre, 2009 , p. 15). Such differences may gain from being investigated in order to contextualise the 'leaky pipeline' phenomenon and - in a way - contribute to further point out the political nature of gender inequalities among academic labour markets.

\section{Being employable, being mobile: a global trend shaping academic employ- ment?}

By "provid[ing] evidence of a strong societal embeddedness of academic markets" (Goastellec \& von Roten, 2017, p. 227), looking at how national gender regimes shape academic careers points out the political nature of the 'leaky pipeline' phenomenon. The culture and policies related to academic employment, especially the mobility norms vary across given polities, contributing to the same discussion.

For a large number of candidates, having some postdoctoral international mobility reduces the risk of remaining on temporary academic positions (Ortlieb \& Weiss, 2018) and thus to the 'leaky pipeline'. While the link between individual mobility and internationalisation of scientific and intellectual production remains tenuous (Ackers, 2008), the mobility norm also manifests itself at institutional level. Universities aiming to cast themselves as international or global institutions (Musselin, 2017) are keen to look towards attracting and recruiting the 'best brains worldwide' and thus ensure their global competitiveness (Tung, 2008). To do this, universities have introduced structured career progression models, such as tenure tracks where the performance of an academic is assessed periodically; and those who have achieved the pre-set targets will have an opportunity to aspire to the full professor position. International mobility period is often required in these new structured career models (Pietilä 2015; Siekkinen, Pekkola \& Kivistö, 2016).

In general, at the beginning of 2010's only $16 \%$ of European academic staff had experienced international mobility (Goastellec \& Pekari 2013, 2016). As the norm of academic mobility at the institutional and international level is becoming stronger in most national academic contexts, practices and policies framing this norm strongly differ across countries. The mobility norm and its effect are stronger within 'small' countries like Switzerland, Norway, Ireland or Austria, although mobility is often regional rather than strictly international (Goastellec, 2016). There is similarly a disciplinary aspect to the mobility norm: 'being mobile' appears to be a stronger prerequisite for being recruited on a permanent position in physics or molecular biology compared with law or humanities. Finally, the attractiveness of local non-academic markets also impacts mobility practices, and young academics' decision to leave the academia: if the chances of getting a stable job outside academia are high; the human and material cost of mobility can be perceived as a good reason for leaving the academic track (Bataille, Le Feuvre, \& Kradolfer Morales, 2017; Dorenkamp \& Weiß, 2017). However, mobility is not only a choice dependent on the individual.

\section{A mixed framework to better under- stand the making of young academics gendered practices and representations}

Even if it is well known that national gender regimes and mobility norms contribute to shape the gender of academic careers, their combined effects on the ways men and women consider embracing an academic career and deal with it have rarely been analysed. This 'mixed' framework, combining national gender regimes and academic mobility norms is at the core of the present chapter. 
We investigate how the international norm of academic mobility influences the academic careers for men and women, depending on the national gender regime in which the academic market they try to access is embedded. Because the temporality of building a family and an academic career are often simultaneous, we focus on men and women who are junior to mid-career academics with a family. Our main research questions include: How do midcareer academics with children envisage international mobility depending on their gender and the national gender regime characterising their country? Does the development of an international mobility requirement in academic careers generate different tensions for both men and women depending on the national gender regimes?

\section{Finland and Switzerland: two comparable but highly contrasted polities}

As previous comparisons between Finland and Switzerland already show (Goastellec \& Välimaa, 2016), these two European countries have much in common: relatively small (Switzerland 8 million and Finland 5.5 million inhabitants) and sparsely populated countries, which both used to be poor and "dominated by their neighbours" (Goastellec \& Välimaa, 2016, p. 105) but are now among the richest countries of Europe. Both have high standard of living and advanced education and science infrastructure. For all these reasons, Finnish and Swiss cases are well fitted for comparison. Nevertheless, Finland and Switzerland strongly differ in terms of our two main variables of interest - national gender regimes and academic mobility practices. Figure 1 presents the proportion of internationally mobile academics - i.e., academics who received their $\mathrm{PhD}$ outside their country of current employment - among junior (A) and senior (B) academic staff in several European countries; with Finland and Switzerland appearing at the opposing ends of the continuum.

In Switzerland, people who defended their $\mathrm{PhD}$ abroad represent $55 \%$ of the senior academic staff and $36 \%$ of the junior academic staff. While there are great differences between disciplines, all in all internationalisation of the Swiss higher education institutions' employees is an old phenomenon; albeit one that has varied during the last century (Rossier, Beetschen, Mach, \& Bühlmann, 2015). International academic recruitments have nevertheless risen sharply since the end of the 1990s, due to the institutional and national policies and norms aiming to promote Swiss universities in the international rankings (Benninghoff, Goastellec, \& Leresche, 2009). The good academic labour market conditions and high salaries can also be strongly appealing for foreign academics, especially those coming from one of the three main neighboured countries, which have experienced a strong precarisation - as in Italy - or a stagnation and a strengthening of internal competition within their own national market since the end of the 1990s.

Conversely, Finland has a relatively small but growing share of international academics, who represent $4 \%$ in senior positions and $9 \%$ in junior positions; albeit national higher education policies and funding in place to support international mobility. In 2015, the Academy of Finland, the country's most prestigious research funding body, changed the preconditions of personal postdoctoral or senior scholar grants to include a minimum six-month work experience in a university other than where they received their $\mathrm{PhD}$. While this precondition by the Academy of Finland is fulfilled with a stay in another Finnish university, many universities' recruitment policies emphasise mobility periods abroad. Data from 2016, however, shows the disparity between $\mathrm{PhD}$ holders who enter the country, and those who exit it: while $495 \mathrm{PhD}$ holders left Finland; only 193 moved to the country (Acatiimi, 2017), sparking concerns of 'brain drain' amongst national media and academic trade unions. The reasons for leaving the university sector as a whole in Finland has been said 


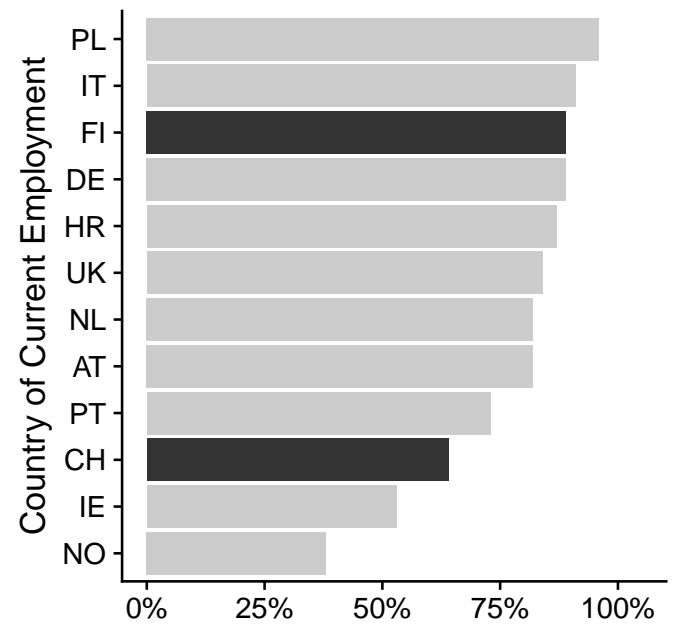

A. Junior Staff

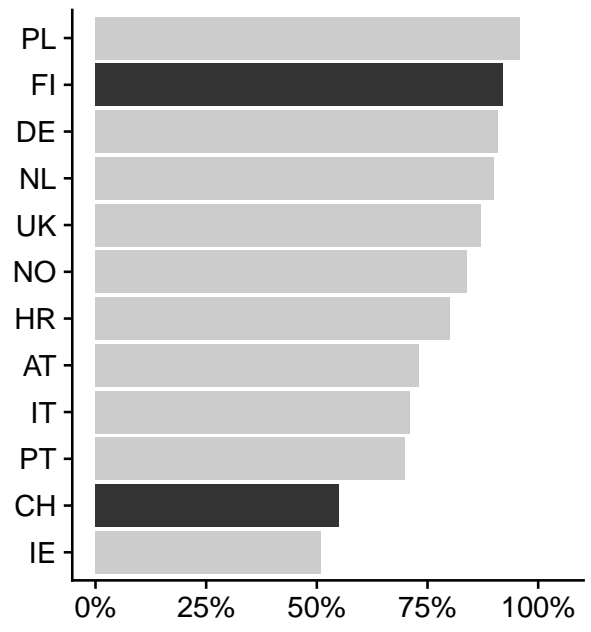

B. Senior Staff

Figure 1: Doctoral Degree Obtained in the Country of Current Employment (European academic staff, 2010) Source: EuroAC

to be related to the decreasing resources of Finnish universities and poor working conditions with short fixed-term contracts (Siekkinen, Kuoppala, Pekkola, \& Välimaa, 2016b).

\section{National gender regimes}

Swiss and Finnish States strongly differ in the ways they support childcare, women's employment and non-traditional family. In Switzerland, there is no parental leave at the federal level (Valarino \& Gauthier, 2016), fiscal policies are unfavourable to dual-earner households and there is a considerable lack of childcare solutions (Bütler, 2006). Conversely in Finland, parental leave lasts for nine months; three of which are earmarked for the mother and the remaining six can be used by either parent. Additionally, there is an earmarked paternity leave of up to nine weeks. The parental allowance is minimum $70 \%$ of the parent's salary. If the child is cared for at home, the parents receive a small sum called the child home care allowance. Also, childcare outside home is heavily subsidised; though the right to full- or part time childcare is dependent on the parents' labour market situation.

These differences between Finland and Switzerland contribute to the observed contrast between the labour market participation of men and women in the two countries (Figure 2). While the primary family labour market configuration in Switzerland comprises men working fulltime and women part time; in Finland, families comprising two full time earners are more common than in many other European countries (UNECE, 2018). This 'double full time active' track also seems strong among families with children.

The differences between the two national gender regimes thus comprise both the family labour market arrangements (Switzerland: male breadwinner female homemaker; Finland: two fulltime earners); and the societal policies that contribute to them namely the childcare and parental leave policies, and other arrangements that impact on both parents' ability to equally participate in the labour market. 


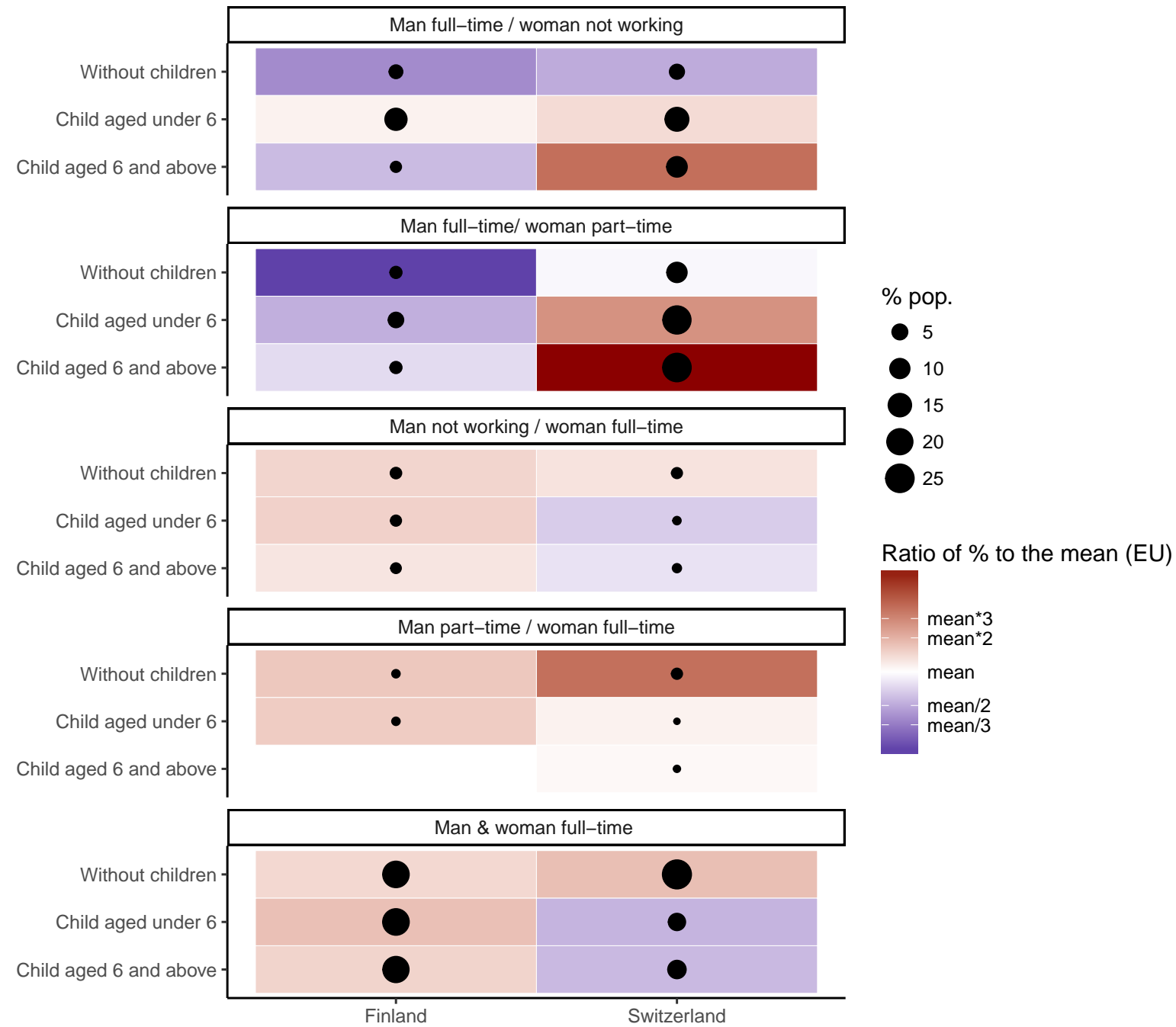

Figure 2: Labour market participation patterns of couples aged 29-45 years, by family labour market configuration (Finland \& Switzerland) 2016

Source: UNECE

These gender regimes are a significant component that impact, respectively, the gender representation of academia in Finland and Switzerland (Figure 3). In Finland, the share of female university students surpassed that of male students already in the 1970s while in Switzerland women remained underrepresented until the 2000s. The makeup of the Swiss and Finnish academic labour markets differs along both the share of male versus female 
academics, and the share of international versus national academics.

Swiss and Finnish academic markets contrast by their level of feminisation (higher in Finland), their level of internationalisation (much higher in Switzerland), and across these two dimensions, by a lower share of internationally mobile women academics compared with men in Finland, while it is not the case in Switzerland.

We therefore question whether the challenges of academic career and mobility are perceived differently by women, compared with men, in the gender regimes of Finland and Switzerland; and whether, thus, men and women talk differently about them.

\section{Data and methods}

The Swiss data was collected in 2015-2016 during the GARCIA Project* aimed at investigating gender asymmetries at the early stages of academic careers in Belgium, Iceland, Italy, Netherlands, Slovenia and Switzerland. Altogether 40 interviews were conducted at a major Swiss research university. The interviewees were selected from among a list of all the people hired in a postdoctoral position between 2010 and 2013 by a STEM or HSS department of this university. This selection aimed to represent the broadest range of characteristics possible. The interviewees comprised both males and females, international and domestic scholars, people employed at the time of the interviews in postdoctoral positions, other academic positions and those working outside academia. For this paper, we focused on those interviewees who were not yet tenured, and had a partner and at least one child $(n=16)$. This subsample comprised seven women and nine men, 34 to 48 years of age. Six of the interviewees represented social or human sciences, and ten represented STEM fields. Of the interviewees, five were Swiss and 11 foreign nationals.

The Finnish dataset was designed to complement the existing Swiss data. It comprised interviews with altogether 16 respondents, located in a Finnish

\footnotetext{
* http://garciaproject.eu/
}

research university. The authors' personal contacts and a link tracing sampling design were used in identifying the interviewees. The interviewees had to be in an early to mid-career stage; having completed their PhD's, but not yet holding full professor positions. For this paper, only those interviewees were selected who had a partner and at least one child. The sample comprised five men and six women; aged 34 to 47 years old. Two of the selected respondents were international, i.e., not Finnish citizens. Seven of the respondents were in life sciences, four in social sciences. Six had spent a longer or shorter period of their career abroad, while five had no international experience during their careers beyond short-term conference trips. Two of the respondents held permanent positions, while the rest were either tenure-track, fixed-term positions or held personal scholarships.

All the interviews were recoded and transcribed; then analysed by several rounds of reading to identify the key themes and dimensions these themes belonged to.

We analysed how interviewees deal - subjectively and objectively - with imperatives about four main topics at the core of our research interest: family, career, work-life balance and internationalisation. We thus interrogate how the interviewees construct internationalisation and international mobility, how they talk about their academic careers; how they describe the relationship between family and career; and finally, how they balance work and family responsibilities, and talk about their routines and coping mechanisms.

\section{Analysis}

\section{Internationalisation}

The first dimension addressed internationalisation as part of academic work and career. 


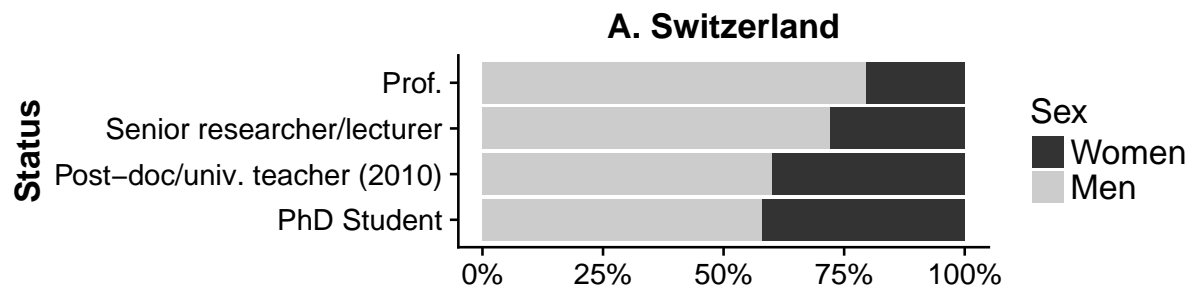

\section{B. Finland}

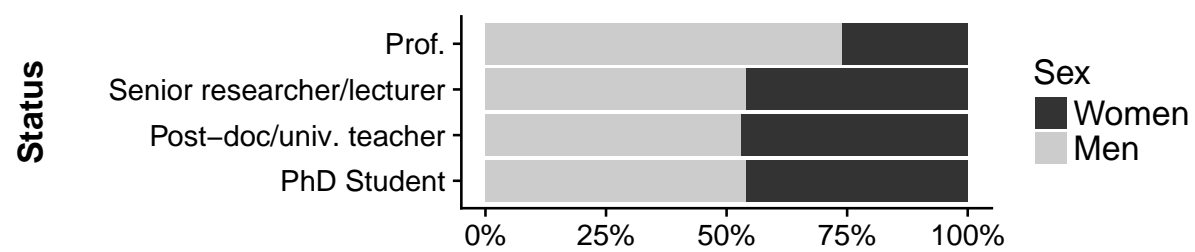

Figure 3: Swiss and Finnish HE staff gendered composition (2014)

Source: FSO and Vipunen, Education Statistics Finland

\begin{tabular}{lll|ll} 
& \multicolumn{2}{c|}{ Finland } & \multicolumn{2}{c}{ Switzerland } \\
\cline { 2 - 5 } & Male & Female & Male & Female \\
\hline National & 4 & 5 & 5 & 7 \\
International & 1 & 1 & 5 & 7 \\
Permanent contract & 1 & 1 & 2 & 1 \\
Tenure track/In the process of & 1 & 1 & 2 & 3 \\
being made permanent & 2 & 4 & - & 1 \\
Fixed-term & 1 & - & 2 & 2 \\
Scholarhip & - & - & 11 & 14 \\
Out & 4 & 4 & - & - \\
Period abroad & 1 & 4 & 7 & 6 \\
No period abroad & 3 & 2 & 4 & - \\
Life sciences & 2 & $34-47$ & - & -
\end{tabular}

Table 1: Itw sample composition

\section{Finland}

In the Finnish interviews, internationalisation is primarily constructed as attending international conferences or spending mid-length periods between a few months to one year abroad in the context of postdoctoral projects funded from Finland. However, 
the idea of leaving Finland for a longer-term career without the intention of coming back was not common amongst the Finnish-born interviewees. For one of the foreign born academics this was their primary goal, and the time spent in Finland was seen more as an interlude, while for the other one, the primary goal was to stay in Finland although this was made challenging by the partner's labour market situation.

The experiences of the mid-length international mobility periods were, to some extent, gendered in that the male interviewees had more mobility experiences than female interviewees, conducted either alone before children were born or with the whole family travelling along during spouse's parental leave. The scholars in life sciences had more and longer mobility periods than the scholars in social sciences. The two international interviewees who were both married to another academic had spent longer periods of time away from their spouse due to both their own and their spouse's academic career.

The representations of internationalisation in the interviews of the Finnish-born scholars were framed by a critique of the perceived 'compulsory internationalisation'; stemming from the tacit and explicit perception that higher education policy and institutions require scholars to spend certain time abroad as a precondition for academic career progression; or in the case of some of the social science respondents, the critical view of the strengthening norm to publish in English instead of in Finnish. The compulsory mobility was described as being based on a very narrow understanding of internationality as a relatively short period of international mobility after $\mathrm{PhD}$, instead of engaging in international collaborative research while staying at the home institution. The futility of simply 'going abroad' for the sake of going abroad was mentioned in several interviews.

Internationalisation has become a responsibility for someone working at the university. If you go abroad for 6 months and you are not well prepared or have poor networks, it may all become to nothing. You do the same writing you would have done at home. (Female, soc. sci.)

Similarly, the interviewees perceived that the dominant higher education discourse assumes that everything that is international, i.e., not Finnish/domestic, must inherently be of higher quality, and many interviewees criticised this view.

Just going abroad will not bring international quality. You have to have the thoughts in your own head already. You don't just go abroad to talk nice and suddenly [that way] the quality of science goes up. Instead, something must change in your own head and take [science] forward. [...] I understand that it is difficult to get Finnish people to leave and go abroad, that is a good reason to try and make them go, it does not hurt anyone [to go]. But I don't understand the hype about making structural decisions that you must have a period abroad in your CV. That is a potential indicator for quality of science, but the main indicators are publications and citations. (Male, life sci.)

The negotiations between family obligations and academic work, including for example teaching obligations, influenced the considerations of shortterm mobility for both men and women, as attending conferences required interviewees to ensure the other parent, or extended family in some cases, was able to take care of the children during the trip. The representations of the challenges related to this were especially prominent amongst women, although male interviewees also indicated they considered carefully whether a trip was worth making. Amongst women there was a sense that mid-length and longer-term mobility was largely ruled out in the near future, not on the account of lacking interest but on family grounds as it would be impracticable because of children's school or other circumstances, such as the spouse's work. Some also cite their personality, as not having been courageous enough to 'go abroad' before, and now, with family, it is difficult. However, as a longer-term perspective, if no jobs were to be found in Finland or when children were already independent, 
they considered international mobility to be at least a theoretical, if not actionable, option. The notion of advancing one's career through mobility was not something seen in the interviews. Rather, the representation of mobility is related to the broader frame of talking about academia as simply a job rather than a career in which one should try to advance. If it is simply a job one is doing, then the benefits accrued by mobility, such as networks, collaboration or access to data and previous research can just as well be managed from the location in Finland.

Internationalisation was one of the issues where the respondents in life sciences and social sciences displayed a clear difference, in a sense life science respondents had much more funding available for attending international conferences, and therefore availability of funding did not feature as a factor in their consideration on whether to travel abroad or not. Meanwhile, the social science respondents had to give consideration to whether they had the funds available to attend conferences. This division was even more visible when considering the entire set of interviews, not just the sample of those respondents with families, selected for this paper, illustrating an important disciplinary gap with regard to funding availability and how it impinges on the possibility (and maybe institutional expectations) of short-term mobility.

\section{Switzerland}

Most of the postdocs interviewed in Switzerland were not originally from Switzerland and had defended their PhDs in France (17\%), the US $(8.5 \%)$ or Italy $(7.9 \%)$. Reflecting the global trends of academic mobility, the movers in the Swiss data mostly came from Europe and North America and - above all - are currently working within this geographical area. Thus, North-to-North mobility is the most frequent pattern of migration among the interviewees in Switzerland. Some of the interviewees came from the global South to Switzerland; and few planned to go back to a Southern country. Thus, as many of the interviewees in the Swiss sample came from abroad, they were predisposed to have a good opinion on international mobility.

[With my wife] we both like... we like to travel a lot. My wife [who is Swiss], she has family in the US, she has family in Germany so... Me too I'm German actually. So, we're pretty international family, so we like to see other cultures and to, to go abroad. So, when she agreed that she would come with me and that she would also like to do a postdoc [...], we went to the US, to look at different place we also thought about ok where are groups where she could work with. And then once we have decided we started to apply also to the different labs in the different departments which were available. (Male, life sci.)

For those interviewees who defended their dissertation in Switzerland and who spent their first postdoctoral years in the same country, going abroad and getting international mobility experience was often presented as necessary for reaching a tenuretrack position in a Swiss university. At the same time, the strong internationalisation of the Swiss academic labour markets makes, however, the return to Switzerland after a mobility period a risky strategy:

If you want a job in Switzerland you are competing with the world in fact, unlike other countries where it is more you are more in competition with local people. Switzerland is a completely open market [...] We are very international so it's not easy to come back to Switzerland at this level. (Male, life sci )

Thus, even some of the Swiss interviewees criticised the mobility norm, which was mostly seen as a necessary ingredient of academic career. This was particularly the case in life sciences, where international mobility period is more often a 
prerequisite for career advancement than in social sciences. Nevertheless, the Swiss social sciences interviewees also mentioned international mobility during postdoctoral years as a prerequisite to being competitive on the Swiss academic market.

In Switzerland, therefore, we are obliged to go abroad [...]. When you have a family, it's true that this rule is really hard. And then afterwards, like all that, it's done to promote excellence, to see what is part of the research, to be a bit international, to be aware of what is going on, done elsewhere and well it fit well in the professional academic culture. [Colleagues often say] "It will be very good for you to go elsewhere because you will be able to meet new people and so on". And yeah so in that sense you're still pushed to ask [a postdoc fellowship]. (Female, soc.sci.)

The critical discourse on the mobility norm, prevalent amongst the Finnish interviewees, was also found amongst some, albeit few, of the Swiss interviewees. While such mobility norm had different implications for women and men, the mobility norm seemed to be ingrained in the representation of an academic career.

\section{Career}

\section{Finland}

The respondents mostly felt optimistic about their future career, despite having been employed on short-term contracts now or in the past. They also recognised that academics often encounter competition in building and maintaining an academic career, and were aware of the general precariousness of academic careers.

While all responders indicated that they were happy being researchers, most nevertheless indicated that this was not the only option for them, and in case it was not possible to pursue further a university career, they could do something else. While the two citations below appear gendered, the data does not allow us to determine this conclusively.

Somehow I have thought that why would I think about it (precariousness) too much; if this is my dream job, I will do it as long as it works out. (Male, life sci.)

I think future is not so grim as people paint it. I try to remain positive and believe in my own abilities. Something will always show up. Maybe my future will be elsewhere and I will be in a company rather than university in five years' time. [...] I also see no point in that I would try [ to get funding] for years, as that would certainly lead to desperation. (Female, life sci.)

This notion was typically tied to the family dimension indicating that changing career was preferable to changing geographic location. Two interviewees, one male, one female, further qualified this by stating that their identity was not linked to a given position at the university. Such hedging was also accompanied by the recognition that university careers were precarious and did not easily allow for career breaks.

There were subtle differences between the interviewees in terms of whether they referred research as a career/vocation, or as a job like any other.

My problem is just to figure out what I like more than this. I really love mentoring, you know, I really love doing research. The parts of academia that I hate have to do with things that are very difficult to change you know; the pay, the structure, you know the way that they see woman in science or mothers, you know, in science. Those kinds of things are difficult, the instability, you know, that stuff is hard to change. But everything else about it, you know like doing my research, I love. (Female, life sci.) 
Most interviewees indicated they had been lucky in acquiring the posting they currently had, instead of attributing it to their own excellence or hard work. Two men mentioned that they did not think they would be amongst the first people to be let go, if the university was laying off staff.

\section{Switzerland}

Amongst the Swiss interviewees as well, there were people who spoke of their future in terms of career building, even if they knew that their chances of reaching a permanent position in Switzerland were low. Those career-oriented people were often men, in a relationship with a partner working outside academia, and holding lower education than themselves.

Going out was pretty straightforward [yeah]. [...] So I did my PhD in [another Swiss university] [...] I stayed almost one complete year as a postdoc in a lab where I did my $\mathrm{PhD}$ and during that time. I started to, you know, look at other laboratories, in particular in... in other countries, 'cos I wanted to go somewhere else, and which I'm interested in... Actually, all the laboratories I got really interested in were in the US. So I started to contact them, and then during the summer I went to the US for a road trip. We visited different places to see whether we could imagine living there. (Male, life sci.)

While few women spoke similarly of mobility, they were typically either single or in 'atypical' conjugal configuration; such as with a partner who had a lower educational background or an 'egalitarian' way of thinking about gender relationships.

I think I applied for other two places and I didn't know anything about it [salary and so one]. And then I got this one [a postdoctoral position in Germany]. I had to decide. When they took me, they said "yes you have two weeks to decide". And I said "yes" ... and then after that I didn't apply anymore. But I'd say at the same time also my husband was applying for other positions. And we were kind of decided: once one of us get first something that is decent, we move. (Female, life sci.)

Swiss interviewees also perceive the international competition to influence academic careers, causing them to experience stress and doubt about their future in academia although some also presented the pressure as normal for academic careers.

I don't suffer but sometimes I think, ok, you know it's normal that you're sometimes stressed and, hum, and that you can't sleep. I talk to other people here and they sometimes have the same problems that you just have lot of responsibilities and a lot of work from different sides. (Male, life sci.)

The level of satisfaction with the employment conditions at the university among Swiss postdocs is lower than among their foreigner counterparts. This low satisfaction may lead some postdocs to leave their academic careers and pursue alternative career paths in the private or public sector. (Bataille et al., 2017). The relative precariousness of academic careers was a topic brought up by nearly all interviewees, and included stories about fix-term employment contracts followed by spells of unemployment. The accounts provided by those who left their academic career track were, in particular, shaped by their gendered expectations for the future. The following extract is illustrative of the discourse of those men who viewed the academic career prospects too uncertain compared with opportunities outside academia; and decided to exit the academic labour market. Discussing the reason why he decided to quit academia for a job at an industrial firm, the (male, life sci.) interviewee said, "I didn't want to end up being over 40 and still with a fixed-term contract". 
Since PhDs are highly valued on the nonacademic Swiss labour markets, the career-oriented interviewees had a choice of taking a position in a company or in public administration in case their career progression in academia stalled.

\section{Family}

\section{Finland}

Most interviewees argued that their partner was very supportive in everyday life, though some have more flexibility than others to support the respondent's career or contribute to the family duties, depending on their own work situation. Interestingly, most interviewees argued that they did not think having a family impeded their career; yet having a family was definitely a factor to be taken into account when considering job location or international mobility. Many interviewees stated that they would rather change career than location due to family ties; partner's career cited typically as a reason for not moving abroad or moving to a different city. Stability for children was deemed very important (schools, friends, health care), and consequently, many of the interviewees stated that they were more likely to pursue international mobility when their children were older. This statement was often linked to the critical sentiment expressed towards 'compulsory' internationalisation, which is further discussed under the internationalisation theme. Another popular way to describe potential mobility plans and the role of family was to say that the whole family could go, or indeed has gone, abroad for a short while. Although the sample is too small to draw extensive conclusions about this, it is worth noting that men, rather than women primarily conveyed such experiences; and that such a visit had taken place while their wife had been on parental leave. Similarly, the respondent could be or has been travelling alone for just a few weeks or months. However, long terms plan to relocate the family were on hold due to the consideration of the spouse's employment and aspirations, as illustrated by this quote:
I could go by myself, if I did not have to think about children's schools and care, and wife's job. I know that my wife will not want to become a housewife abroad, she wants to do something else as well. (Male, soc. sci.)

The international respondents recognised that finding jobs for their partners (in both cases the partner was an academic) might be challenging if the family stayed in Finland. However, the desire to 'put down roots' for the sake of the family, in Finland or elsewhere was a topic addressed also in the international interviews; where the partners had already experienced long periods of staying apart in different countries:

In the next two-plus years that I have left of my personal grant, I will be applying for jobs to try and get something that will allow us to just lay down roots. [...] I hope that once I apply for jobs in North America, if I get something, many universities there are better with a twobody situation, in that they will do double hires. (Female, life sci.)

There were small differences in the Finnish interviews between men and women with regard to this dimension. One characteristic of the family issue was about treating the family as a unit instead of individuals and their careers.

\section{Switzerland}

Since family policies are less favourable for women in Switzerland, the family theme was not prominent, and was primarily negative among Swiss interviewees in general - especially for those who had left Switzerland for a long period. Family was, therefore, more commonly mentioned among people who presented themselves as suffering in the academic system and/or who were thinking leaving the academic career sooner or later. 
I was doing a postdoc in London and my family did stay here. My husband had a fixed position with also responsibilities... so it wasn't possible to leave his job to just spend a year in London. We also had a place in a crèche here. So, finally everything was established and we did not want to just move for a year knowing that uh well this was a postdoc - so not a stable position that I will have. So the family stayed here so it's me who makes the trips. And then uh here I was already exhausted before leaving and this situation really didn't make the things get better. (Female, soc sci.)

While there were some men who shared this discourse, women (and especially Swiss women) were overrepresented among those who put the family at the core of their narratives on work and career.

\section{Work-life balance}

\section{Finland}

The last dimension addresses questions pertaining to work-life balance, as well as pacing and balancing together the family and career obligations in the daily life. A dualism that was clearly identifiable in the Finnish data was the notion that academic work requires a lot in terms of daily life, and one often has to prioritise work ahead of family; working long hours and during holidays was described as common. At the same time, a majority of the interviewees iterated that academic work also offers a lot of flexibility in everyday life as it does not require one to spend fixed hours in the office, but can instead be done flexibly and in various places, if family obligations require one to leave the office early.

[I probably work] $7 \mathrm{~h}$ in the office and it depends a lot on the current work situation how much follows in the in the remaining hours and potentially weekend. [...] It is a luxury to work on something that I also like doing, and difficult to distinguish what is work and what is not. But on the other hand it is also difficult to completely disconnect from work, e.g. go on holiday and not take any papers. (Male, life sci.)

While some social science respondents stated they tried to focus their work on office hours, most also work occasional evenings or weekends. A clear departure from this were those life science respondents who had experimental work or field work, as that kind of work was not tied to conventional working hours, but extended to weekends or, for example, very long working days in the summertime. Perhaps surprising was the ethos represented by the interviewees that they primarily relied on the nuclear family in managing family obligations, instead of making use of wider circles of family, friends or proprietary services. One interviewee even criticised that academic discourse prioritises work, and assumes that family is there to support work, and argued that it would be better to think that the "people close to us should bring something else to our lives than facilitating more work" (Male, soc sci.).

\section{Switzerland}

In the Swiss data, the work overflowing into private life was commonly presented as normal. Similar to the Finnish data, the interviewees in life sciences faced this challenge more directly than interviewees in social sciences, as they often reported having to work at the lab during the weekends or in the evenings.

Personally I try to keep to that work rate 8 a.m. .. 8 a.m. to 6 p.m. roughly. I know that a lot of my colleagues come later in the morning and end very late in the evening or work at weekends, etc. In any case it's more than a $100 \%$ job [ok] not me though, not in my case. (Male, life sci.)

Women, who had to manage between the flexibility of academic daytime work and the lack of affordable 
childcare, often declared that they suffered from the lack of boundaries between the private and professional spheres.

To be frank personally I'm not proud of what I've done so far [during her postdoc], so I don't know how much patience he [her supervisor] has, I don't know how reasonable he finds it that I... well I feel terribly handicapped compared to what I, what... what I used to do in the time of the... when I had free use of my time, and well now there are so many constraints in all directions plus the fact that in terms of family all the same it's an enormous sacrifice [yeah] I'm neglecting my little daughter four days a week and also incidentally my bloke. (Female, life sci.)

\section{Discussion and conclusion}

Our analysis highlights the similarities and differences in the ways in which male and female academics talk about their careers, mobility and family life and the ways they cope with combining these different spheres in Finland and Switzerland. While the calls for international mobility are present in both polities, the norm seems stronger and less contested in Switzerland than in Finland, where the representations of the mobility norm were more critical. In Finland, there were little differences in terms of how men and women talked about balancing their academic career and family responsibilities. They were also equally critical about the discourse of enforced international mobility, bar that of short-term conferences or visits. In Switzerland, the differences between men and women on these topics were more important. While Swiss men often declared that going abroad before having a tenured position was normal, Swiss women were more critical on this issue - and those who experienced mobility were often pushed to a very difficult situation, especially if they were in partnership with educated Swiss men (Bataille et al., 2017). Similarly, there were differences between Finland and Switzerland in terms of how the interviewees talked of family and work-life balance. Family seemed to be harder to reconcile with an academic career than in the Finnish interviews; and the representations of family were mostly negative.

Previous research show that women are still underrepresented in academia both in terms of institutional leadership higher rungs of the professorial posts or in terms of achieving tenured positions, especially in STEM fields (Goulden et al., 2011) and in full time and permanent positions (Goastellec \& Pekari, 2013). Women are also disadvantaged as reviewers, authors and guest editors in scholarly journals (e.g. Nature 2018). Scientific outputs presumed written by men are rated higher than those presumed written by women (Knobloch-Westerwick, Glynn, \& Huge, 2013). Women lose out on research funding (van der Lee \& Ellemers, 2005); and are at a disadvantage when it comes to forming and benefitting from academic networks (Vázquez-Cupeiro \& Elston, 2006), including that they feel uncomfortable forming networks for career advancement purposes (Nokkala, Culum, \& Fumasoli, 2016). Minority ethnicity or nonheteronormative identity are also factors that can work to disadvantage academics, cause discrimination, and compromise career advancement (Gutierrez y Muhs, Niemann, Gonzalez, \& Harris, 2012). These various aspects of disadvantages play out to greater or lesser degrees in different societal contexts.

In addition to the policies and structures that challenge women's path to senior academic jobs, also the university culture emphasising efficiency, control and strong management (Deem, 1998; Evetts, 2009) as well as the more 'masculine' elements of the university are argued to be inconsistent with the feminine, embodied motherhood (Huopalainen \& Satama, 2018). This leads to an ongoing negotiation between being a 'good' academic and a 'good' mother, a process loaded with gendered norms and expectations. Both roles have their ideal that "seems to emphasise full devotion, commitment, professionalisation and high performance" (Huopalainen \& Satama, 2018, p. 17). 
Nikunen (2014, p. 14) also describes how new "meritocratic transparency and entrepreneurialism are difficult to combine with family responsibilities" when flexibility and "individual" means not just academic freedom but responsibility and long working hours. Families are left alone trying to solve their challenges with work-life balance issues and mobility requirement with little social support (Nikunen, 2014).

Our results reflect the different gender regimes in the two countries; which make combining a family with an academic career more difficult in Switzerland than in Finland. The gender regimes are policies-inaction; the extent to which the norm of international mobility has permeated the Swiss discourse also reflects the openness of the Swiss academic labour markets, and respectively, the relative closure of the Finnish ones. However, this may change in the future as Finnish universities also strive to recruit more of their staff internationally.

Illuminating the embeddedness of academic careers in the national gender regimes, our results give rise to a contemplation of policy implications for higher education institutions and national policy-makers alike. Recognising the structures and practices that support or impinge on women's academic careers, such as availability of childcare services and parental leave arrangements that facilitate equal division of family responsibilities, is the first step towards more gender equality in academia. Flexible mobility arrangements and financial support for mobility periods that enable the mobility for the entire family may make it easier for women to combine family responsibilities with the requirements for academic mobility. Cultural norms about family division of labour are harder to change, though. The first step is, however recognising that the meritocracy in academia disguise a let of structures and practices, embedded in the academic and societal institutions that impinge on women's careers. These structures and practices also go some way towards illuminating the various reasons behind the leaky pipeline phenomenon, which sees scores of women leaving academic careers or ending up in less prestigious positions in the academic hierarchy. But one might also more largely interrogate the pertinence of international mobility as an absolute constraint to access an academic career, as well as the place allocated to (academic) work in individual's life with regard to family life, i.e., the normative incentives nurturing the multiple social roles people have to articulate. But this is probably a whole other story.

\section{References}

Acatiimi (2017). Osaamisvaihtotase yhä enemmän miinuksella. Acatiimi. Accessed August 2017, from http://www.acatiimi.fi/8_2017/3.php

Acker, J. (1994). The gender regime of Swedish banks. Scandinavian Journal of management, 10(2), 117-130. https://doi.org/10.1016/ 0956-5221(94) 90015-9

Ackers, L. (2008). Internationalisation, Mobility and Metrics: A New Form of Indirect Discrimination? Minerva, 46(4), 411-435. DOI 10.1007/s11024-0089110-2

Bataille, P., Le Feuvre, N., \& Kradolfer Morales, S. (2017). Should I stay or should I go? The effects of precariousness on the gendered career aspirations of postdocs in Switzerland. European educationnal research journal, 16(2-3), 313-331. https://doi.org/10.1177/1474904116673372

Benninghoff, M., Goastellec, G., \& Leresche, J.P. (2009). L'international comme ressource cognitive et symbolique : changements dans l'instrumentation de la recherche et de l'enseignement supérieur en Suisse. In J.-P. Leresche, P. Larédo, \& K. Weber (Eds.), Recherche et Enseignement Supérieur Face à l'Internationalisation. France, Suisse et Union.

Bozzon, R., Murgia, A., \& Poggio, B. (2018). Gender and precarious careers in academia and research. In A. Murgia \& B. Poggio (Eds.), The Precarisation of Research Careers: A Comparative Gender Analysis (pp. 15-49). Londres: Routledge. https://doi.org/10.4324_9781315201245-2. 
Bütler, M. (2006). Le rendement effectif du travail pour les familles avec des petits enfants. St Gallen University: Public Economy Dept.

Deem, R. (1998). 'New managerialism' and higher education: The management of performances and cultures in universities in the United Kingdom, International Studies in Sociology of Education, 8(1), 4770. https://doi.org/10.1080/0962021980020014.

Dorenkamp, I., \& Weiß, E.-E. (2017). What makes them leave? A path model of postdocs' intentions to leave academia. Higher Education, online publication. https://doi.org/10.1007/s10734-017-0164-7.

Dubois-Shaik, F., Fusulier, B., \& Vincke, C. (2018). A gendered pipeline typology in academia. In A. Murgia \& B. Poggio (Éd.), The Precarisation of Research Careers: A Comparative Gender Analysis (p. 178-205). Londres: Routledge. https://doi.org/10.4324_9781315201245-7.

Eggins, H. (Ed.). (2017). The Changing Role of Women in Higher Education: Academic and Leadership Issues. Basel: Springer International Publishing.

EuroAC (2013), The Academic Profession in Europe: Responses to Societal Challenges (2009-2013). Accessed September 2018, from https://www . uni-kassel.de/einrichtungen/ incher/forschung/wissenschaftlicher-wandel/ euroac-academic-profession-in-europe.html.

Evetts, J. (2009). New professionalism and new public management: changes, continuities and consequences. Comparative sociology, 8(2), 247-266. https://doi.org/10.1163/156913309X421655

GARCIA Project. Accessed September 2018, from http://garciaproject.eu/

Goastellec, G. (2016). La mobilité internationale[202F?]: une qualité des carrières et des marchés académiques en Europe[202F?]? Journal of international Mobility, 1(4), 171-188. https://doi. org/10.3917/jim.004.0171

Goastellec, G., \& Pekari, N. (2013). Gender Differences and Inequalities in Academia: Findings in Europe. In U. Teicher, \& E. E. Höhle (Eds.), The Work Situation of the Academic Profession in
Europe: Findings of a Survey in Twelve Countries (pp. 55-78). Dordrecht: Springer.

Goastellec, G., \& von Roten, F. C. (2017). The Societal Embeddedness of Academic Markets: From Sex to Gender in the Swiss Context. In M. MachadoTaylor, V. Soares, \& U. Teichler (Eds.), Challenges and Options: The Academic Profession in Europe (pp. 211--229). Cham: Springer.

Goastellec, G., \& Välimaa, J. (2016). Expliquer les inégalités d'accès aux diplômes en Finlande et en Suisse (1950-2004)[202F?]: des structures scolaires aux politiques sociales. Education et sociétés, 2(38), 105-121.https://doi.org/10.3917/es.038.0105

Goulden, M., Mason, M. A., \& Frasch, K. (2011). Keeping women in the science pipeline. The ANNALS of the American Academy of Political and Social Science, 638(1), 141-162. https://doi.org/10.1177/0002716211416925

Gutierrez y Muhs, G., Niemann, Y. F., Gonzalez, C. G., \& Harris, A. P. (Eds.), 2012. Presumed Incompetent: The Intersections of Race and Class for Women in Academia. Logan, UT: Utah State University Press.

Huopalainen, A.S., \& Satama, S.T. (2018). Mothers and researchers in the making: Negotiating "new" motherhood within the "new" academic. Human relations, online publication. https://doi. org/10.1177/0018726718764571.

Knobloch-Westerwick, S., Glynn, C. J., \& Huge, M. (2013). The Matilda effect in science communication: an experiment on gender bias in publication quality perceptions and collaboration interest. Science Communication, 35(5), 603-625. https://doi.org/10.1177/1075547012472684

Lahire, B. (1998) L'Homme Pulriel. Paris: Nathan.

Le Feuvre, N. (2009). Exploring women's academic careers in cross-national perspective. Lessons for equal opportunity policies. Equal Opportunities International, 28(1), 9-23. https://doi.org/10. 1108/02610150910933604

Leca, J. (2012). L'Etat entre politics, policies et polity. Gouvernement et action publique, 1 (1), 59-82. https://doi.org/10.3917/gap.121.0059 
Musselin, C. (2017). La Grande course des universités. Paris: Presses de Sciences Po.

Nature (2018). Nature's under-representation of women. Nature, 558, 344.Retrieved September 2018, from https://doi.org/10.1038/ d41586-018-05465-7

Nikunen, M. (2014). The entrepreneurial university, family and gender: changes and demands faced by fixed-term workers. Gender and Education, 26 (2), 119-134. https://doi.org/10.1080/ 09540253.2014 .888402

Nokkala, T., Culum, B., \& Fumasoli, T. (2016). Early Career Women in Academia: An Exploration of Networking Perceptions. In H. Eggins (Ed). The Changing Role of Women in Higher Education (pp. 267-290). Basel: Springer International Publishing.

FSO (2016). Personnel des institutions de formation. Edition 2016. Federal Stastistical Office, Bern.

Ortlieb, R., \& Weiss, S. (2018). What makes academic careers less insecure? The role of individuallevel antecedents. Higher Education, online publication. https://link.springer.com/article/10 . 1007/s10734-017-0226-x.

Pietilä, M. (2015). Tenure Track Career System as a Strategic Instrument for Academic Leaders. European Journal of Higher Education. 5(4), 371387. https://doi.org/10.1080/21568235. 2015. 1046466

Rogers, R., \& Molinier, P. (Éd.). (2016). Les femmes dans le monde académique. Perspectives comparatives. Rennes: Presses universitaires de Rennes.

Rossier, T., Beetschen, M., Mach, A., \& Bühlmann, F. (2015). Internationalisation des élites académiques suisses au XXe siècle[202F?]: convergences et contrastes. Cahiers de la recherche sur l'éducation et les savoirs, (14), 119-139.

Siekkinen, T., Pekkola, E. \& Kivistö, J. (2016a). Recruitments in Finnish universities: Practicing strategic or pathetic HRM? Nordic Journal of Studies in Educational Policy, (2-3), online publication. https://doi.org/10.3402/nstep.v2.32316

Siekkinen, T., Kuoppala, K., Pekkola, E., \& Välimaa, J. (2016b). Reciprocal commitment in academic careers? Finnish implications and international trends. European Journal of Higher Education, 7(2), 120-135. https://doi.org/10.1080/21568235.2016.1248990

Tung, R. L. (2008). Human Capital or Talent Flows: Implications for Future Directions in Research on Asia Pacific, Asia Pacific Business Review, 14(4), 469-472. https://doi.org/10.1080/ 13602380802037714

UNECE (2018). Couples by working patterns: Gender Statistics, UNECE/STAT. Accessed September 2018, from http://w3.unece.org/ PXWeb2015/pxweb/en/STAT/STAT__30-GE__98-GE_ LifeBalance

Valarino, I., \& Gauthier, J.-A. (2016). Paternity leave implementation in Switzerland: a challenge to gendered representations and practices of fatherhood? Community, Work \& Family, 19(1), 1-20. https://doi.org/10.1080/13668803.2015. 1023263

Välimaa, J., Stenvall, J., Siekkinen, T., Pekkola, E., Kivistö, J., Kuoppala, K., Nokkala, T., Aittola, H., \& Ursin, J. (2016). Neliportaisen tutkijanuramallin arviointihanke: Loppuraportti. Opetus- ja kulttuuriministeriön julkaisuja 2016:15. Helsinki: OKM.

van der Lee, R., \& Ellemers, N. (2005). Gender contributes to personal research funding success in the Netherlands. Proceedings of the National Academy of Sciences of the United States of America, 112(40), 12349-12353. https://doi.org/10.1073/pnas.1510159112

Vipunen (2018). Education Statistics Finland. Accessed September 2018, from https://vipunen. fi/en-gb/

Vázquez-Cupeiro, S., \& Elston, M. A. (2006). Gender and academic career trajectories in Spain: From gendered passion to consecration in a Sistema Endogámico? Employee Relations, 28(6), 588-603. https://doi.org/10.1108/01425450610704515 